\title{
Purchasing pattern of bakery products among working and non-working women in Central India: Effect of socio-economic factors
}

\section{Mayura Kathane ${ }^{1}$, Rekha Sharma ${ }^{2}$}

1 - Post Graduate Teaching Department of Home Science, Rashtrasant Tukadoji Maharaj Nagpur University, Nagpur, India

2 - UGC-Human Resource Development Centre, Rashtrasant Tukadoji Maharaj Nagpur University, Nagpur, India

Keywords:

Purchasing pattern

Bakery

Bread

Biscuits

Cake

Buns

Pizza bread

Article history:

Received 15.03.2017

Received in revised

form 02.05.2017

Accepted 29.06.2017

Corresponding author:

Mayura Kathane

E-mail:

mayurakathane@

gmail.com

DOI: $10.24263 / 2304-$ 974X-2017-6-2-16

\section{Abstract}

Introduction. Bakery products are items of mass consumption in view of its low price and high nutrient value. With rapid growth and changing eating habits of people, bakery products have gained popularity among masses.

Materials and Methods. About 200 working and 200 non-working women were selected by simple random sampling method from Central India, Maharashtra, India and the data was collected using interview cum questionnaire method. Purchasing pattern of five bakery products viz., bread, buns, biscuit, cake and pizza bread were studied with respect to age group, qualification, family size, number of earning members and family monthly income of the working and nonworking women.

Results and Discussion. The results of the study showed that the average age of working women was $39.39 \pm$ 6.15 years and non-working women was $38.36 \pm 5.7$ years. The average monthly income of working and non-working women was Rs. $38,125 \pm 19,550$ and Rs. 40,625 $\pm 20,825$ respectively. Bread was found to be the most consumed bakery products among both types of families $(79.5 \%$ in working and $83.5 \%$ non-working) followed by biscuits (76.5\% in working and 70.5\% non-working). The purchasing of buns, cake and pizza bread among working women were $7.5 \%, 19 \%$ and $14 \%$ whereas among nonworking families it was $13 \%, 23 \%$ and $18.5 \%$ respectively. The significant associations were observed between the purchasing pattern of bread $(p=0.000)$, biscuits $(p=0.000)$ and cake $(p=0.010)$ with the educational status of working and non-working women. The age group, family size, number of earning members and monthly income of working and non-working women did not show any association with the purchasing pattern of bakery products.

Conclusion. Purchasing of bakery products was same in both working and nonworking women. Among demographic characteristics, education of women significantly affected the purchasing pattern of bakery products. 


\section{Introduction}

Increasing urbanization, lifestyle changes, more number of working women and nuclear families are some of the major factors leading to the rise in demand for processed foods all over the world. Shift in economic power and demographics and empowered consumers are expected to change consumer food preference. This trend is resulting in greater consumer expectations with regards to safety, quality, integrity and traceability of food across all emerging economics [1]. Consumption of bakery products was not in the Indian culture; however with changing eating habits of the people and with rising western influence on food consumption patterns, bakery products today have got takers from all age groups in the country. Bakery products are items of mass consumption in view of its low price and high nutrient value. With rapid growth and changing eating habits of people, bakery products have gained popularity among masses. The sector typically constitutes bread, cake and biscuits [2].

Bakery market research is a necessity because the knowledge of specific correlations determines positive effects both for producers who can properly size the activities, and consumers who can purchase their desired products in the quantities required, the price appropriate for their purchasing power and in the preferred range [3]. Several scientists [4, $5,6]$ have carried out studies on buying behavior and consumer preference of different bakery products and its association with socio economic status of families. The average expenditure on Biscuits has a positive relationship with innovative buying behavior, social factors, health factors, lifestyle and pester power [6]. The demographic variables such as age group, gender and occupation are having less impact on the factors of customer satisfaction [5]. Various important factors that affect the behavior of the customer consuming Biscuits are packaging, pricing, availability, quality, brand etc [7]. Taste was the most important factor which affects the customers buying decision and least important is nutritional value of the bakery products. The other important factors is the rate that changes the mind of customers [8]. However, there are negligible studies carried out in Central India on purchasing pattern of bakery products, particularly with reference to working and non working women. Hence the present study was proposed to be carried out on purchasing pattern of bakery products of working and non working women in Central India.

The objectives:

1. To study the socio-economic conditions of working and non-working women in Central India.

2. To assess the purchasing pattern of bakery products by working and non-working women of Central India.

3. To study the relationship between purchasing pattern of Bakery products and socioeconomic conditions of working and non-working women of Central India.

\section{Materials and methods}

The present study was conducted in Nagpur City of Central India, Maharashtra, India. About 200 working and non-working women each were selected by judgmental sampling method. The working women were selected from schools, colleges, hospitals and different institutions. The non-working women were selected from kitty parties, temples, gardens etc. A structured questionnaire was developed to assess the socio- economic conditions and purchasing pattern of Bakery products. The questionnaire cum interview method was used to elicit information. Data was tabulated and was analyzed statistically using SPSS version 17. Mean, Standard Deviation and Chi square test were computed and the Confidence Interval was $95 \%$. 


\section{Economics and Management -}

\section{Results and discussion}

\section{Demographic profile of women}

Table 1 shows distribution of working and non-working women according to their demographic profile. The average age of working women was $39.39 \pm 6.15$ years and that of non-working women was $38.36 \pm 5.7$ years. The bakery products today have got takers from all age group in the country [4]. The majority of working women (33\%) were post graduate with additional qualifications whereas majority non-working women were either only graduate $(34 \%)$ or post-graduate $(34.5 \%)$. The working women were significantly $\left(\chi^{2}\right.$ $=53.45, \mathrm{p}=0.000)$ more qualified than that of non-working women. About $50.5 \%$ working and 58\% non-working women were from joint families. Also, majority of both working $(65 \%)$ and non-working $(52.5 \%)$ women had 1 to 4 members in their families and a significant association $\left(\chi^{2}=7.48, p=0.024\right)$ was also observed between the working status of women and family size. The number of earning members were significantly more $\left(\chi^{2}\right.$ $=12.42, \mathrm{p}=000)$ in working women's family $(73 \%)$ as compared to non-working $(58.5 \%)$ women. The average monthly income of working women was Rs. 38,125 $\pm 19,550$ and non-working women was Rs. 40,625 $\pm 20,825$. The average income spent on food by working women was Rs. $8465.5 \pm 5181.08$ and non-working women was Rs.8625 \pm 4716.25. The average monthly income spent on processed food for working and nonworking women was Rs $1093.5 \pm 1126.94$ and Rs $1029 \pm 972.60$ respectively.

\section{Purchasing Pattern of Bakery products}

In the present era growing demand for the bakery products has become one of the most important necessities in the life of the people. Bakery products have become popular among different cross sections of population in recent years due to increased demand for convenient foods. Among bakery products, bread and biscuits are the most popular processed ready-to-eat food items in the country [9]. The purchasing pattern of bakery products by the working and non working women of the present study has been presented in Table 2.

According to Table 2 bread was found to be the most consumed bakery products among both types of families (79.5\% in working and $83.5 \%$ non-working) followed by biscuits $(76.5 \%$ in working and $70.5 \%$ nonworking). The purchasing of buns, cake and pizza bread among working women were $7.5 \%, 19 \%$ and $14 \%$ whereas among nonworking families it was $13 \%, 23 \%$ and $18.5 \%$ respectively. Though an insignificant association was observed between the working status of women and purchasing pattern of bakery products $(\mathrm{p}=0.293)$. 
Table 1

Demographic profile of working and nonworking women

\begin{tabular}{|c|c|c|c|c|c|}
\hline \multirow[b]{2}{*}{ SN } & \multirow[b]{2}{*}{$\begin{array}{l}\text { Demographic } \\
\text { Parameters }\end{array}$} & \multirow[b]{2}{*}{ Category } & \multicolumn{3}{|c|}{ Number of Women } \\
\hline & & & $\begin{array}{c}\text { Working } \\
\mathrm{N}=\mathbf{2 0 0}\end{array}$ & $\begin{array}{c}\text { Non- } \\
\text { working } \\
\mathbf{N}=\mathbf{2 0 0}\end{array}$ & Total \\
\hline \multirow[t]{6}{*}{1} & \multicolumn{5}{|c|}{ Age(Years) } \\
\hline & & $30-35$ & $63(31.5)$ & $71(35.5)$ & 134 \\
\hline & & $36-40$ & $59(29.5)$ & $70(35.0)$ & 129 \\
\hline & & $41-45$ & $39(19.5)$ & $30(15.0)$ & 69 \\
\hline & & $46-50$ & $39(19.5)$ & $29(14.5)$ & 68 \\
\hline & Mean Age M + SD & \multicolumn{2}{|c|}{$39.39 \pm 6.1$} & \multicolumn{2}{|c|}{$38.36 \pm 5.7$} \\
\hline \multirow[t]{5}{*}{2} & Qualification & Undergraduate & $14(7.0)$ & $5(2.5)$ & 19 \\
\hline & & Graduate & $28(14.0)$ & $68(34.0)$ & 96 \\
\hline & & Graduate + & $54(27.0)$ & $33(16.5)$ & 87 \\
\hline & & Post Graduate & $38(19.0)$ & $69(34.5)$ & 107 \\
\hline & & Post Graduate+ & $66(33.0)$ & $25(12.5)$ & 91 \\
\hline \multirow[t]{2}{*}{3} & Family Type & Nuclear & $99(49.5)$ & $84(42.0)$ & 183 \\
\hline & & Joint & $101(50.5)$ & $116(58.0)$ & 217 \\
\hline \multirow[t]{3}{*}{4} & Family Size & $1-4$ members & $130(65.0)$ & $105(52.5)$ & 235 \\
\hline & & 5-0 members & $69(34.5)$ & $91(45.5)$ & 160 \\
\hline & & $\begin{array}{l}\text { Above } 10 \\
\text { members }\end{array}$ & $1(0.5)$ & $4(2.0)$ & 5 \\
\hline \multirow[t]{3}{*}{5} & Earning Members & 1 member & $17(8.5)$ & $117(58.5)$ & 134 \\
\hline & & 2 member & $146(73.0)$ & $47(23.5)$ & 193 \\
\hline & & above2 members & $37(18.5)$ & $36(18.0)$ & 73 \\
\hline \multirow[t]{4}{*}{6} & Monthly Income(Rs) & Up to 25,000 & $57(28.5)$ & $43(21.5)$ & 100 \\
\hline & & $25,000-50,000$ & $77(38.5)$ & $71(35.5)$ & 148 \\
\hline & & Above 50,000 & $66(33.0)$ & $86(43.0)$ & 152 \\
\hline & M + SD & \multicolumn{2}{|c|}{$38,125 \pm 19,550$} & \multicolumn{2}{|c|}{$40,625 \pm 20,825$} \\
\hline \multirow[t]{4}{*}{7} & $\begin{array}{l}\text { Monthly Income Spent on } \\
\text { food (Rs) }\end{array}$ & Up to 10,000 & $162(81.0)$ & $164(82.0)$ & 326 \\
\hline & & 11000 to 20000 & $35(17.5)$ & $34(17.0)$ & 69 \\
\hline & & Above 20000 & $3(1.5)$ & $2(1.0)$ & 5 \\
\hline & $\mathbf{M}+\mathbf{S D}$ & \multicolumn{2}{|c|}{$8465.5 \pm 5181.08$} & \multicolumn{2}{|c|}{$8625 \pm 4716.25$} \\
\hline \multirow[t]{4}{*}{8} & $\begin{array}{l}\text { Monthly Income Spent on } \\
\text { Processed Foods (Rs) }\end{array}$ & Up to 10000 & $149(74.5)$ & $159(79.5)$ & 308 \\
\hline & & 11000 to 20000 & $37(18.5)$ & $28(14.0)$ & 65 \\
\hline & & Above 20000 & $14(7.0)$ & $13(6.5)$ & 27 \\
\hline & M + SD & \multicolumn{2}{|c|}{$1093.5 \pm 1126.94$} & \multicolumn{2}{|c|}{$1029 \pm 972.60$} \\
\hline
\end{tabular}

(Numbers in parenthesis indicates percent cases.) 
Table 2

Distribution of women consumers according to purchasing pattern of bakery products

\begin{tabular}{|c|c|c|c|c|}
\hline \multirow{2}{*}{ Bakery Products } & \multicolumn{2}{|c|}{ Women } & \multirow{2}{*}{ Total } & \multirow{2}{*}{$\chi^{2}$ and $p$ value } \\
\hline & Working & Non-working & & \\
\hline Bread & $159(79.5)$ & $167(83.5)$ & 326 & \multirow{5}{*}{$\begin{array}{c}\chi^{2}=4.938 \\
\mathrm{p}=0.293\end{array}$} \\
\hline Buns & $15(7.5)$ & $26(13)$ & 41 & \\
\hline Biscuits & $153(76.5)$ & $141(70.5)$ & 294 & \\
\hline Cake & $38(19)$ & $46(23)$ & 84 & \\
\hline Pizza Bread & $28(14)$ & $37(18.5)$ & 65 & \\
\hline
\end{tabular}

(Numbers in parenthesis indicates per cent cases.)

\section{Bread}

According to Indian Bakery Industry, bread is a hygienically manufactured and packed snack food product available at comparatively cheap prices. Major consumers of bread are people from the lower middle class. It is also the most commonly available bakery product [2]. Though bread is not a staple food in the country, its consumption has increased over the years. In India it is still a secondary staple food when compared to chapatti, puri or rice [10]. Distribution of women of the present study according to demographic profile and purchasing of pattern of bread has been presented in Table 3.

Table 3

Distribution of women according to demographic profile and purchasing pattern of Bread

\begin{tabular}{|c|c|c|c|c|}
\hline \multirow[t]{2}{*}{ SN } & \multirow[b]{2}{*}{ Demographic parameters } & \multicolumn{2}{|c|}{ Women } & \multirow{2}{*}{$\begin{array}{l}\chi^{2} \text { and } p \\
\text { value }\end{array}$} \\
\hline & & $\begin{array}{c}\text { Working } \\
N=159\end{array}$ & $\begin{array}{c}\text { Non-working } \\
\mathbf{N}=167\end{array}$ & \\
\hline 1 & \multicolumn{4}{|c|}{ Age in years } \\
\hline & 30-35 & $53(26.5)$ & $59(29.5)$ & \multirow{4}{*}{$\begin{array}{c}\chi^{2}=1.685 \\
p=0.640\end{array}$} \\
\hline & $36-40$ & $46(23.0)$ & $56(28.0)$ & \\
\hline & $40-45$ & $33(16.5)$ & $29(14.5)$ & \\
\hline & $46-50$ & $27(13.5)$ & $23(11.5)$ & \\
\hline 2 & \multicolumn{4}{|c|}{ Qualification } \\
\hline & Undergraduate & $12(6.0)$ & $4(2.0)$ & \multirow{5}{*}{$\begin{array}{c}\chi^{2}=48.526 \\
p=0.000\end{array}$} \\
\hline & Graduate & $17(8.5)$ & $58(29.0)$ & \\
\hline & Graduate+ & $50(25.0)$ & $30(15.0)$ & \\
\hline & Post graduate & $32(16.0)$ & $55(27.5)$ & \\
\hline & Post graduate+ & $48(24.0)$ & $20(10.0)$ & \\
\hline \multirow[t]{5}{*}{3} & \multicolumn{4}{|c|}{ Family Size } \\
\hline & 1 to 4 members & $100(50.0)$ & $91(45.5)$ & \multirow{3}{*}{$\begin{array}{c}\chi^{2}=2.947 \\
p=0.229\end{array}$} \\
\hline & 5 to 10 members & $58(29.0)$ & $73(36.5)$ & \\
\hline & 11 and above members & $1(0.5)$ & $3(1.5)$ & \\
\hline & \multicolumn{4}{|c|}{ Earning Members } \\
\hline 4 & 1 to 2 members & $130(65.0)$ & $138(69.0)$ & \multirow{3}{*}{$\begin{array}{c}\chi^{2}=1.506 \\
p=0.471\end{array}$} \\
\hline & 3 to 4 members & $24(12.0)$ & $27(13.5)$ & \\
\hline & 5 or more members & $5(2.5)$ & $2(1.0)$ & \\
\hline 5 & \multicolumn{4}{|c|}{ Monthly Income(Rs.) } \\
\hline & $<25000$ & $43(21.5)$ & $34(17.0)$ & \multirow{3}{*}{$\begin{array}{c}\chi^{2}=2.835 \\
p=0.242\end{array}$} \\
\hline & 25000 to 50000 & $59(29.5)$ & $60(30.0)$ & \\
\hline & $>50000$ & $57(28.5)$ & $73(36.5)$ & \\
\hline
\end{tabular}

(Numbers in parenthesis indicates per cent cases.) 
The result from Table 3 shows that the purchasing of bread in both working $(26.5 \%)$ and non-working women $(29.5 \%)$ in 30-35 years of age group was highest whereas it was found to be lowest in the 46-50 years of group (working women $13.5 \%$ and non-working women $11.5 \%$ ). The general trend indicated that with an increase in age group of women, there is a decrease in the purchasing of bread in the family. However an insignificant association $(\chi 2=1.685, \mathrm{p}=0.640)$ was observed between the age group of women and purchasing pattern of bread in the family. Families exercise some of the most important social and group influence on individual consumer decision. The fundamental demographic forces of age, marital status and presence of children in the family can together place a major role in shaping individual and point purchase behavior [11].

According to qualification, the usage of bread was found significantly more in nonworking graduate $(29 \%)$ and graduate with additional qualification $(25 \%)$ in working women category. With the decrease in education level, the increase in purchasing of bread was observed. The purchasing was found to be lowest in undergraduate category for both non-working $(2 \%)$ and working $(6 \%)$ women. The purchasing of bread was significantly associated $\left(\chi^{2}=48.526, p=0.000\right)$ with educational status of women. A study reports that young generation mostly prefer the bakery product and they are mostly popular in urban areas, due to awareness and literacy [9].

It was further observed that the purchasing of bread was highest in families with 1 to 4 members in both categories (50\% in working women and $45.5 \%$ non-working women). With the increase in number of family members, the decrease in purchasing of bread was observed. Table 3 clearly depicts that there was negligible purchasing of bread in families having more than 11 members in both working $(0.5 \%)$ and non-working women $(1.5 \%)$. However, no significant association $(\chi 2=2.947, \mathrm{p}=0.229)$ was observed between the number of family members and purchasing pattern of bread.

While analyzing the data based on earning members in a family, it was found that most of the consumers were from the families having 1-2 earning members in both working $(65 \%)$ and non-working $(69 \%)$ women. It was also found that as the number of earning members in a family increased the purchasing of bread decreased. For families having more than five earning members, the purchasing was very minimal in both working $(2.5 \%)$ and non-working women $(1 \%)$. But no association $(\chi 2=1.506, \mathrm{p}=0.471)$ was observed between the number of earning members and purchasing of bread.

The consumers of bread were least in both working $(21.5 \%)$ and non-working women (17\%) categories where the monthly income was less than Rs. 25000. The maximum purchasing of bread based on income groups was found to be in Rs. 25000-50000 category for working women $(29.5 \%)$ and whereas in case of non-working women $(36.5 \%)$ it was in the greater than Rs. 50000 category. An insignificant association $(\chi 2=2.835, p=0.242)$ was observed between the monthly income and consumers of bread. The major consumers of bread are people from the lower middle class and economically weaker segments consuming more than 90 per cent of the bread industry's total production. Bread is the cheapest and basic instant food available for consumption [12]. The most important amongst all is price of bread which decides whether to buy or not. Some people are very particular about the colour, taste, flavour and texture of bread [8].

\section{Buns}

Burger is a salty bakery product and is made of buns and various vegetables. Burger is a readymade product available immediately on demand and it needs no time to prepare. India also has its share of fast food with Samosa, Vada pav, Parathas and various types of 
chats [13]. Distribution of women of the present study according to demographic profile and purchasing of pattern of buns has been presented in Table 4.

Table 4

Distribution of Women according to Demographic profile and purchasing pattern of Buns

\begin{tabular}{|c|c|c|c|c|}
\hline \multirow[t]{2}{*}{ SN } & \multirow{2}{*}{$\begin{array}{c}\text { Demographic } \\
\text { Parameters }\end{array}$} & \multicolumn{2}{|c|}{ Women } & \multirow[b]{2}{*}{$\chi^{2}$ and $p$ value } \\
\hline & & $\begin{array}{c}\text { Working } \\
N=15\end{array}$ & $\begin{array}{c}\text { Non-working } \\
\mathbf{N}=\mathbf{2 6}\end{array}$ & \\
\hline 1 & \multicolumn{4}{|c|}{ Age (years) } \\
\hline & $30-35$ & $2(1.0)$ & $7(3.5)$ & \multirow{4}{*}{$\begin{array}{c}\chi^{2}=1.753 \\
p=0.625\end{array}$} \\
\hline & $36-40$ & $7(3.5)$ & $13(6.5)$ & \\
\hline & $41-45$ & $2(1.0)$ & $2(1.0)$ & \\
\hline & $46-50$ & $4(2.0)$ & $4(2.0)$ & \\
\hline 2 & \multicolumn{4}{|c|}{ Qualification } \\
\hline & Undergraduate & $0(0.0)$ & $0(0.0)$ & \multirow{5}{*}{$\begin{array}{c}\chi^{2}=5.896 \\
p=.117\end{array}$} \\
\hline & Graduate & $2(1.0)$ & $9(4.5)$ & \\
\hline & Graduate+ & $4(2.0)$ & $5(2.5)$ & \\
\hline & Post graduate & $4(2.0)$ & $10(5.0)$ & \\
\hline & Post graduate+ & $5(2.5)$ & $2(1.0)$ & \\
\hline 3 & \multicolumn{4}{|c|}{ Family Size } \\
\hline & 1 to 4 members & $10(5.0)$ & $15(7.5)$ & \multirow{3}{*}{$\begin{array}{c}\chi^{2}=0.322 \\
p=.570\end{array}$} \\
\hline & 5 to 10 members & $3(1.5)$ & $6(3.0)$ & \\
\hline & 11 and above members & $2(1.0)$ & $5(2.5)$ & \\
\hline 4 & \multicolumn{4}{|c|}{ Earning Members } \\
\hline & 1 to 2 members & $14(7 \%)$ & $22(11 \%)$ & \multirow{3}{*}{$\begin{array}{c}\chi^{2}=0.891 \\
p=.641\end{array}$} \\
\hline & 3 to 4 members & $1(0.5)$ & $3(1.5)$ & \\
\hline & 5 or more members & $0(0.0)$ & $1(0.5)$ & \\
\hline 5 & \multicolumn{4}{|c|}{ Monthly Income(Rs.) } \\
\hline & $<25000$ & $3(1.5)$ & $2(1.0)$ & \multirow{3}{*}{$\begin{array}{c}\chi^{2}=1.561 \\
\mathrm{p}=.458\end{array}$} \\
\hline & 25000 to 50000 & $6(3.0)$ & $10(5.0)$ & \\
\hline & $>50000$ & $6(3.0)$ & $14(7.0)$ & \\
\hline
\end{tabular}

(Numbers in parenthesis indicates per cent cases.)

The study from Table 4 clearly shows that the usage of buns was very limited in both working and non-working women categories. The purchasing of buns was found to be highest in 36-40 years age group in working (3.5\%) and non-working women $(6.5 \%)$. The purchasing was lowest in 41-45 years age group of working women (1.0\%) non-working women $(1.0 \%)$. An insignificant association $(\chi 2=1.753, \mathrm{p}=0.625)$ was found between age groups and purchasing of buns.

The purchasing of buns was found to be more in non-working $(5 \%)$ post graduate women and working post graduate with additional qualification of women $(2.5 \%)$. It was observed that as the education level increases, the purchasing of buns also increases. Though, insignificant association $(\chi 2=5.896, \mathrm{p}=0.117)$ was observed between the purchasing of buns and qualification.

The purchasing of bun was highest for families having 1- 4 family members in both working (5\%) and non-working women (7.5\%). As the number of family members increase, the purchasing of bun decreases. No purchasing was found in families with more 
than 11 members, hence no significant association $(\chi 2=0.322, p=0.570)$ was found between purchasing of bun and family members. In Meerut Region, there is a healthy demand of Burgers among the children, youths and adults due to its good taste, high calorific value, easy accessibility and reasonable price. But like other bakery products its demand is confined to urban areas [9]. Burger is most preferred Fast Food items by younger generation which prove that they preferred Fast Food items because of its taste, variety and quality which tells about their consciousness towards food [14].

The higher purchasing of bun was noted in families of working $(7 \%)$ and non-working women $(11 \%)$ with less number of earning members (one to two members). As the numbers of earning members increases the (more than five) the purchasing of bun decreases in non working women $(0.5 \%)$ and no purchasing was observed in more than five earning members group. Although no association $\left(\chi^{2}=0.891, \mathrm{p}=0.641\right)$ was established between purchasing of bun and the number of earning members.

The purchasing of bun was higher in the high income group Rs $>50000$ in both working (3\%) and non-working women (7\%) as compared to low income group $\mathrm{Rs}<25000$ in both working $(1.5 \%)$ and non-working women $(1 \%)$. It was found that as the income increased the purchasing of bun also increased. However monthly income and purchasing of bun did not show significant association $(\chi 2=1.561, \mathrm{p}=0.458)$ between them.

\section{Biscuit}

Confectionaries like cake and biscuits have vital importance among the public irrespective of the age, sex and the preference of the individual in all parts of the world. So, from childhood to retirement age every one of used to take biscuits as a delicious food during morning and evening tea breaks. Children up to age group of up to a particular age limit they consume more amount of confectionary items [4]. The Indian biscuit sector is dominated by players like Britannia, Parle and Sunfeast brand [15]. From the Britannia Good Day Biscuit research, it is inferred that majority of $54 \%$ respondents are consuming Britannia biscuits and majority of 66\% respondents coming under age group 15-25 years are consuming Britannia biscuits and $70 \%$ of male are consuming Britannia biscuits. The demographic variables such as age group, gender and occupation are having less impact on the factors of customer satisfaction [5]. Distribution of women of the present study according to demographic profile and purchasing of pattern of biscuit has been presented in Table 5 .

Above data from Table 5 clearly shows that the purchasing of biscuits was highest in $30-35$ age group of working (24.5\%) and 36-40 age group of non-working women (26.5\%). The purchasing of biscuits was lowest in $41-45$ age group of working $(13.5 \%)$ and non-working women $(10 \%)$. However, no significant association $(\chi 2=2.461, \mathrm{p}=0.482)$ was observed between the age group and purchasing of biscuits.

The purchasing of biscuits was found to be more for post graduate working women with additional qualification (28\%) and graduate non-working women (26\%). Least purchasing was found for the undergraduate women in both working $(6 \%)$ and non-working (2\%) women category. It was observed that as the education level increases, the purchasing of biscuits also increases. A significant association $(\chi 2=43.394, \mathrm{p}=0.000)$ was observed between the non-working women educational qualification and the purchasing of biscuits. 
Table 5

Distribution of women according to demographic profile and purchasing pattern of Biscuits

\begin{tabular}{|c|c|c|c|c|}
\hline \multirow[b]{2}{*}{ SN } & \multirow[b]{2}{*}{ Demographic Parameters } & \multicolumn{2}{|c|}{ Women } & \multirow[b]{2}{*}{$\chi^{2}$ and $p$ value } \\
\hline & & $\begin{array}{c}\text { Working } \\
\mathrm{N}=153 \\
\end{array}$ & $\begin{array}{c}\text { Non-working } \\
\mathrm{N}=141 \\
\end{array}$ & \\
\hline 1 & \multicolumn{4}{|c|}{ Age (years) } \\
\hline & 30-35 & $49(24.5)$ & $43(21.5)$ & \multirow{4}{*}{$\begin{array}{l}\chi^{2}=2.46 \\
p=0.482\end{array}$} \\
\hline & 36-40 & $45(22.5)$ & $53(26.5)$ & \\
\hline & $40-45$ & $27(13.5)$ & $20(10.0)$ & \\
\hline & $46-50$ & $32(16.0)$ & $25(12.5)$ & \\
\hline \multirow[t]{6}{*}{2} & \multicolumn{4}{|c|}{ Qualification } \\
\hline & Undergraduate & $12(6.0)$ & $4(2.0)$ & \multirow{5}{*}{$\begin{array}{c}\chi^{2}=3.394 \\
p=0.000\end{array}$} \\
\hline & Graduate & $20(10.0)$ & $52(26.0)$ & \\
\hline & Graduate+ & $39(19.5)$ & $24(12.0)$ & \\
\hline & Post graduate & $26(13.0)$ & $42(21.0)$ & \\
\hline & Post graduate + & $56(28.0)$ & $19(9.5)$ & \\
\hline \multirow[t]{4}{*}{3} & \multicolumn{4}{|c|}{ Family Members } \\
\hline & 1 to 4 members & $98(49)$ & $75(37.5)$ & \multirow{3}{*}{$\begin{array}{c}3.75 \\
p=0.197\end{array}$} \\
\hline & 5 to 10 members & $54(27.0)$ & $64(32.0)$ & \\
\hline & 11 and above members & $1(0.5)$ & $2(1.0)$ & \\
\hline \multirow[t]{4}{*}{4} & \multicolumn{4}{|c|}{ Earning Members } \\
\hline & 1 to 2 members & $123(61.5)$ & $115(57.5)$ & \multirow{3}{*}{$\begin{array}{l}\chi^{2}=3.37 \\
p=0.185\end{array}$} \\
\hline & 3 to 4 members & $24(22.0)$ & $25(12.5)$ & \\
\hline & 5 or more members & $6(3.0)$ & $1(0.5)$ & \\
\hline 5 & \multicolumn{4}{|c|}{ Monthly Income(Rs.) } \\
\hline & $<25000$ & $42(21.0)$ & $30(15.0)$ & \multirow{3}{*}{$\begin{array}{c}\chi^{2}=3.703 \\
p=0.157\end{array}$} \\
\hline & 25000 to 50000 & $58(29.0)$ & $47(23.5)$ & \\
\hline & $>50000$ & $53(26.5)$ & $64(32.0)$ & \\
\hline
\end{tabular}

(Numbers in parenthesis indicates per cent cases.)

The lesser the number of family members, higher the purchasing of biscuit in the family and vice versa was observed. Likewise the purchasing of biscuit was more in the family with one to four members in both working $(49 \%)$ and non- working women $(37.5 \%)$. Purchasing goes down in family with 11 and more members in both working $(0.5 \%)$ and non working women $(1 \%)$. However no association $(\chi 2=3.755, \mathrm{p}=0.153)$ was observed between the family size and purchasing of biscuit. A study on factors influencing consumer decision making process towards biscuits showed that parents and children were more or less equally involved in decision making [16].

The highest usage of biscuit was found in families with one to two earning members in both working (61.5\%) and non-working women (57.5\%). The lowest usage of biscuit was found in families with five or more earning members in both working $(3 \%)$ and nonworking women $(0.5 \%)$. However insignificant association $(\chi 2=3.377, \mathrm{p}=0.815)$ was observed between the earning members in the family and purchasing of biscuit.

The purchasing of biscuit showed different trends in working and non working women in monthly income categories. The purchasing of biscuit was found to be increasing as the income of the family increases. The purchasing of biscuit was highest in those families 
whose monthly income was in between Rs 25000 to 50000 of working women (29.5\%) and monthly income Rs. $>50000$ of non-working women $(32 \%)$. No association $(\chi 2=3.703$, $\mathrm{p}=0.157$ ) was observed between the monthly income and purchasing of biscuit. The average expenditure on Biscuits has a positive relationship with Innovative buying behaviour, Social factors, Health factors, Lifestyle and Pester Power [6]. The reason for buying Sunfeast Biscuits is its quality and while few of them prefers it for its low prices. About 39 respondents are consuming for its quality, 28 respondents prefer for its price, 23 respondents are consuming for taste, and 12 respondents prefer for its packages [17]. Various important factors that affect the behaviour of the consumer consuming biscuits are packing, pricing, availability, quality, brand etc [7].

\section{Cake}

Cakes are used in all parties and on all happy occasions. Mostly the young generation has developed the taste of this item. But the use of cakes is mostly confined to urban areas. These are not very popular in rural areas due to its low accessibility. It is not available everywhere except big bakeries [9]. Distribution of women of the present study according to demographic profile and purchasing of pattern of cake has been presented in Table 6 .

Table 6

Distribution of women according to demographic profile and purchasing pattern of Cake

\begin{tabular}{|c|c|c|c|c|}
\hline \multirow[t]{2}{*}{ SN } & \multirow[b]{2}{*}{ Demographic Parameters } & \multicolumn{2}{|c|}{ Women } & \multirow[b]{2}{*}{$\chi^{2}$ and $p$ value } \\
\hline & & $\begin{array}{c}\text { Working } \\
\mathbf{N}=\mathbf{3 8}\end{array}$ & $\begin{array}{c}\text { Non-working } \\
\mathrm{N}=46\end{array}$ & \\
\hline 1 & \multicolumn{4}{|c|}{ Age( years) } \\
\hline & 30-35 & $17(8.5)$ & $20(10.0)$ & \multirow{4}{*}{$\begin{array}{c}\chi^{2}=5.454 \\
p=.141\end{array}$} \\
\hline & $36-40$ & $8(4.0)$ & $18(9.0)$ & \\
\hline & $40-45$ & $7(3.5)$ & $6(3.0)$ & \\
\hline & $46-50$ & $6(3.0)$ & $2(1.0)$ & \\
\hline \multirow[t]{6}{*}{2} & \multicolumn{4}{|c|}{ Qualification } \\
\hline & Undergraduate & $3(1.5)$ & $1(0.5)$ & \multirow{5}{*}{$\begin{array}{c}\chi^{2}=13.377 \\
\mathrm{p}=.010\end{array}$} \\
\hline & Graduate & $6(3.0)$ & $16(8.0)$ & \\
\hline & Graduate+ & $11(5.5)$ & $5(2.5)$ & \\
\hline & Post graduate & $4(2.0)$ & $14(7.0)$ & \\
\hline & Post graduate+ & $14(7.0)$ & $10(5.0)$ & \\
\hline \multirow[t]{4}{*}{3} & \multicolumn{4}{|c|}{ Family Size } \\
\hline & 1 to 4 members & $24(12.0)$ & $26(13.0)$ & \multirow{3}{*}{$\begin{array}{c}\chi^{2}=1.086 \\
p=.581\end{array}$} \\
\hline & 5 to 10 members & $14(7.0)$ & $19(9.5)$ & \\
\hline & 11 and above members & $0(0.0)$ & $1(0.5)$ & \\
\hline \multirow[t]{4}{*}{4} & \multicolumn{4}{|c|}{ Earning Members } \\
\hline & 1 to 2 members & $30(15.0)$ & $37(18.5)$ & \multirow{3}{*}{$\begin{array}{c}\chi^{2}=0.036 \\
p=.982\end{array}$} \\
\hline & 3 to 4 members & $7(3.5)$ & $8(4.0)$ & \\
\hline & 5 or more members & $1(0.5)$ & $1(0.5)$ & \\
\hline \multirow[t]{4}{*}{5} & & thly Incom & (Rs.) & \\
\hline & $<25000$ & $13(6.5)$ & $9(4.5)$ & \multirow{3}{*}{$\begin{array}{c}\chi^{2}=2.895 \\
p=.235\end{array}$} \\
\hline & 25000 to 50000 & $14(7.0)$ & $17(8.5)$ & \\
\hline & $>50000$ & $11(5.5)$ & $20(10.0)$ & \\
\hline
\end{tabular}

(Numbers in parenthesis indicates per cent cases.) 
The data presented in Table 6 shows the distribution of women and purchasing of pattern of cake. The highest purchasing of cake was found for age group 30-35 in both working $(8.5 \%)$ and non-working women $(10 \%)$. The lowest purchasing of cake was found for age group 46-50 in both working (3\%) and non-working women (1\%). The purchasing of cakes is more in the younger age group under consideration in this study and it goes down gradually as we move to the elder age groups. However no association $(\chi 2=5.454$, $\mathrm{p}=0.141$ ) was observed between the age group and purchasing of cake.

The purchasing of cake was found to be more in post graduate with additional qualification of working (7\%) and graduate non-working women $(8 \%)$. Least purchasing was found for the undergraduate women in both working $(1.5 \%)$ and non-working $(0.5 \%)$ category. It was observed that as the education level increases, the purchasing of cake also increases. A significant association $(\chi 2=13.377, \mathrm{p}=0.010)$ was observed between the nonworking women's educational qualification and the purchasing of cake. The education level of the survey respondents predominantly shops customers who have a high school education (52.7\%). Most of the customers bakery is dominated by a student or students as many as 89 people or 36.3 per cent, private sector employees 54 people, or 22 percent, selfemployed, housewives, other work and rest, which owns the smallest percentage of employees the country as many as 10 people or 4.1 percent [18].

Purchasing of cake was found to be highest for families with one to four family members in both working (12\%) and non-working women (13\%). Purchasing of cake was found to be lowest for families with more than 10 family members in both working $(0 \%)$ and non-working women $(0.5 \%)$. It was observed that as the number of family members increased, the purchasing of cake decreased. However, no significant association $(\chi 2$ $=1.086, \mathrm{p}=0.581$ ) was observed between the number of family members and purchasing of cake.

Purchasing of cake was found to be highest for families with one to two earning members in both working (15\%) and non-working women (18.5\%). Purchasing of cake was found to be lowest for families with more than four earning members in both working $(0.5 \%)$ and non-working women $(0.5 \%)$ category. It was observed that as the number of earning family members increased, the purchasing of cake decreased. However, insignificant association $(\chi 2=0.036, \mathrm{p}=0.982$ ) was observed between the number of earning family members and purchasing of cake.

Highest purchasing of cake was found to be for families with income between Rs. 25000-50000 for working (7\%) women. For non-working $(10 \%)$ women the same was found to be for families with income more than Rs.50000. Purchasing of cake was found to be lowest for families with monthly income Rs. $<25000$ in both working $(6.5 \%)$ and nonworking women $(4.5 \%)$ category. It was observed that as the monthly income of family increased, the purchasing of cake also increased. However, no association $(\chi 2=2.895$, $\mathrm{p}=0.235$ ) was observed between the monthly income of family and purchasing of cake.

\section{Pizza bread}

Pizza is a round shaped bakery product. It is the most common fast food popular among the people especially the youths and the children. It is salty in taste. It is made in many flavours such as cheese pizza, onion capsicum pizza, mushroom, pizza etc. It needs various raw materials to prepare it. It is prepared on pizza base pasting cream on it and adding vegetables, cheese, mushroom, spices sauce etc [9]. Distribution of women of the present study according to demographic profile and purchasing of pattern of pizza bread has been presented in Table 7. 
Table 7

Distribution of women according to demographic profile and purchasing pattern of Pizza Bread

\begin{tabular}{|c|c|c|c|c|}
\hline \multirow[b]{2}{*}{ SN } & \multirow[b]{2}{*}{ Demographic Parameters } & \multicolumn{2}{|c|}{ Women } & \multirow[b]{2}{*}{$\chi^{2}$ and $\mathbf{P}$ Value } \\
\hline & & $\begin{array}{c}\text { Working } \\
\mathbf{N}=\mathbf{2 8}\end{array}$ & $\begin{array}{c}\begin{array}{c}\text { Non-working } \\
\mathbf{N}=\mathbf{3 7}\end{array} \\
\end{array}$ & \\
\hline 1 & \multicolumn{4}{|c|}{ Age (years) } \\
\hline & $30-35$ & $11(5.5)$ & $10(5.0)$ & \multirow{4}{*}{$\begin{array}{c}\chi^{2}=2.886 \\
p=0.410\end{array}$} \\
\hline & $36-40$ & $8(4.0)$ & $16(8.0)$ & \\
\hline & $40-45$ & $7(3.5)$ & $6(3.0)$ & \\
\hline & $46-50$ & $2(1.0)$ & $5(2.5)$ & \\
\hline \multirow[t]{6}{*}{2} & \multicolumn{4}{|c|}{ Qualification } \\
\hline & Undergraduate & $1(0.5)$ & $0(0.0)$ & \multirow{5}{*}{$\begin{array}{c}\chi^{2}=7.133 \\
p=0.129\end{array}$} \\
\hline & Graduate & $6(3.0)$ & $17(8.5)$ & \\
\hline & Graduate + & $6(3.0)$ & $4(2.0)$ & \\
\hline & Post graduate & $7(3.5)$ & $11(5.5)$ & \\
\hline & Post graduate+ & $8(4.0)$ & $5(2.5)$ & \\
\hline \multirow[t]{4}{*}{3} & \multicolumn{4}{|c|}{ Family Size } \\
\hline & 1 to 4 members & $12(6.0)$ & $20(10.0)$ & \multirow{3}{*}{$\begin{array}{c}\chi^{2}=2.841 \\
\mathrm{p}=0.242\end{array}$} \\
\hline & 5 to 10 members & $16(8.0)$ & $15(7.5)$ & \\
\hline & 11 and above members & $0(0.0)$ & $2(1.0)$ & \\
\hline \multirow[t]{4}{*}{4} & \multicolumn{4}{|c|}{ Earning Members } \\
\hline & 1 to 2 members & $18(9.0)$ & $29(14.5)$ & \multirow{3}{*}{$\begin{array}{c}\chi^{2}=2.434 \\
p=0.296\end{array}$} \\
\hline & 3 to 4 members & $9(4.5)$ & $8(4.0)$ & \\
\hline & 5 or more members & $1(0.5)$ & $0(0.0)$ & \\
\hline \multirow[t]{4}{*}{5} & & Monthly Inc & & \\
\hline & $<25000$ & $8(4.0)$ & $3(1.5)$ & \multirow{3}{*}{$\begin{array}{c}\chi^{2}=5.351 \\
p=0.069\end{array}$} \\
\hline & 25000 to 50000 & $8(4.0)$ & $10(5.0)$ & \\
\hline & $>50000$ & $12(6.0)$ & $24(12.0)$ & \\
\hline
\end{tabular}

(Numbers in parenthesis indicates per cent cases.)

Table 7 shows the distribution of women according to demographic profile and purchasing pattern of pizza bread. The highest purchasing of pizza bread was found for age group 30-35 in working (5.5\%) women whereas in non-working women (6\%) for 36-49 years of age group. The lowest purchasing of pizza bread was found for age group 46-50 in both working $(1 \%)$ and non-working $(2.5 \%)$ women. However insignificant association $(\chi 2$ $=2.886, \mathrm{p}=0.410$ ) was observed between the age group and purchasing of pizza bread.

It was found that the purchasing of pizza bread was more in non-working graduate women $(8.5 \%)$ and working post graduate with additional qualification women (4\%). Less purchasing was found for undergraduate working women $(0.5 \%)$ and no purchasing was found in non-working undergraduate women category. It was observed that as the education level increases the purchasing of pizza bread also increases. Hence insignificant association $(\chi 2=7.133, p=0.129)$ was observed between the educational qualification and the purchasing of pizza bread.

Purchasing of pizza bread was found to be highest for families with 5-10 family members in working $(8 \%)$ and one to four family members in non-working women $(10 \%)$ 


\section{Economics and Management -}

category. No significant association $(\chi 2=2.841, \mathrm{p}=0.242)$ was observed between the number of family members and purchasing of pizza bread.

Purchasing of pizza bread was found to be highest for families with 1 to 2 earning members in both working (0\%) and non-working women (14.5\%). However, insignificant association $(\chi 2=2.434, \mathrm{p}=0.296)$ was observed between the number of earning members in the family and purchasing of pizza bread.

The purchasing of pizza bread was found to be more for families with income more than Rs. 50,000 in both working (6\%) and non-working (12\%) women. As the income of the family increases, the purchasing of pizza bread also increases. Less purchasing of pizza bread was found to be for families with income less than Rs. 25,000 for both working (4\%) and non-working $(1.5 \%)$ women. The purchasing of pizza bread was insignificantly associated $(\chi 2=5.351, \mathrm{p}=0.069)$ with monthly income for non-working women category.

\section{Conclusion}

The present study was undertaken to assess the purchasing pattern of bakery products viz., bread, buns, biscuits, cake and pizza bread among working and non-working women in Nagpur city. Bread was the most purchased bakery items followed by biscuits, cakes, pizza bread and buns and did not show significant association with the working status of women $(p=0.293)$. The educational qualification of working and non-working women showed significant associations with the purchasing of bread $(\mathrm{p}=0.000)$, biscuits $(\mathrm{p}=0.000)$ and cake $(\mathrm{p}=0.010)$. Demographic characteristics viz., age, family size, earning members and monthly income did not show any significant associations with purchasing pattern any of the bakery products.

\section{References}

1. (2015), Available at: https://www.pwc.in/ winning-consumer-trust, accessed on 24.12.15, pp. 1-28.

2. (2015), Available at: http://www.researchandmarkets.com/reports/2041431/indian bakery industry, accessed on 15.01.17.

3. Stefan V. (2012), Study Concerning The Buying Behaviour for Bread in Iasi Town, 19, pp. 223-30.

4. Yamuna A., Philip R.N.(2015), A Study On Customer Preferences And Attitudes Towards Britannia Products With Special Reference To Coimbatore District, Inter. $J$. of Business and Administration Research Review, 3(9), pp. 171-77

5. Raj P.T., Ramkumar R., Subramani A.K. (2015), Customer Satisfaction towards Good Day Biscuits, EXCEL Inter. J. of Multidisciplinary Management Studies, 5(6).

6. Ghai S. (2012), An Empirical Analysis On Consumer's Buying Behaviour Towards Biscuits With Reference To NCR, Amity University.

7. Sofat Y., Kumar S., Amandeep, (2016), A Study on Consumer Buying Behaviour Towards Biscuits, Inter. J. in Management and Social Sci., 4(6).

8. Patil H.N., Pol R. (2014), A Study on Effects of Standardized Recipes of Bakery Products in Pune Region, Int. J. of Multidisciplinary Consortium, 1(3), pp. 82-91.

9. Available at:

http://shodhganga.inflibnet.ac.in/bitstream/10603/46792/5/05_chapter\%201.pdf. accessed on 16.1.17. 
10. Available at: http://www.aibma.com/industry.htm (All India Bread Manufacture's Association), accessed on 16.1.17.

11. Wells W., Gubar G.(1966), Life Cycle Concept in Marketing, Journal of Marketing Research, 3, pp. 355-63.

12. Jain P. (2014), Study of the Britannia Bread Category and its Current Positioning Strategy with the Objective of Revitalizing the Brand 'Britannia Bread', SDMIMD, Mysuru, pp. 201-11.

13. Garude R.S., Dani R., Sakore A.,(2011), Impact of Junk Food on society, Sheth N.K.T.T. College of commerce, Khargar Ali, Thane, pp. 1-14.

14. Gaikwad S.P. (2016), An Empirical Sudy of Consumer Buying Behaviour Towards Fast Food in South Mumbai, Inter. J. of Research in Finance and Marketing, 6(7), pp. 64-72.

15. (2017), http://www.niir.org/ present-future-prospects-market-size-statistics-trendsswot-analysis-forecasts-upto-2017, accessed on 15.1.17.

16. Venkateshwaralu H., Kishorekumar M., Rajanath K.(1987), Factors influencing consumer decision making process towards biscuits, Indian Journal of Marketing, 17(11-12), pp. 3-9.

17. Jegan A., Sudalaiyandi S.( 2013), A Study on Consumer Buying Behaviour Towards Various Types of Sun fest (ITC) Biscuits in Kovilpatti, Inter. J. of Current Research, 5(4), pp. 957-60.

18. Pulungan M.I., Sumarwan U., Simanjuntak U. (2016), Effect of Brand Equity Dimension in Purchasing Behaviour, Case Study: Aroma Bakery and Cake Shop in Medan, Journal of Marketing and Consumer Research, 26, pp. 30-39. 